Journal

of Geography

Politics and Society

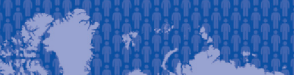

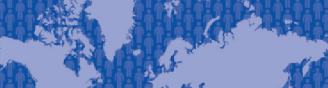

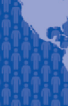

.

\section{Journal of Geography, Politics and Society}

$2018,8(2), 16-25$

DOI 10.4467/24512249JG.18.011.8217

\title{
RUSSIAN-UKRAINIAN RELATIONS IN THE CONTEMPORARY EURASIAN CONTEXT: GEO-ECONOMIC ASPECT
}

\author{
Alexander Druzhinin \\ (1) North-Caucasus Research Institute of Economic and Social Problems, South Federal University, Sadovaya 105, 344006, Rostov-on-Don, Russia, \\ (2) Immanuel Kant Baltic Federal University, Nevsky 14, 236022 Kaliningrad, Russia, \\ e-mail: alexdru9@gmail.com

\section{Citation} \\ Druzhinin A., 2018, Russian-Ukrainian relations in the contemporary Eurasian context: geo-economic aspect, Journal of Geog- \\ raphy, Politics and Society, 8(2), 16-25.
}

\begin{abstract}
The article analyzes the evolution trend of economic ties between Russia and Ukraine over the past quarter century. It is shown that bilateral Russian-Ukrainian relations are experiencing degradation and disaggregation, lose their "exclusivity" due to diminishing "USSR inertia", globalization and the influence of leading "power centers". The new round of geopolitical and geo-economic "redistribution" of the Eurasian space (initiated by the increasing influence of China and the overall "flow" of the economic and demographic potential to the South-East of Eurasia) became the significant challenge for economic cooperation between Russia and Ukraine. The crisis in Russian-Ukrainian relations, unfolding in this context, significantly limits the development opportunities for the both countries, leads to the increase of peripheral traits in their economies, and multiplies dependence on global economic and political actors.
\end{abstract}

\section{Key words}

Russian-Ukrainian relations, foreign economic relations, geo-economics, geopolitics, Russia, Ukraine, Eurasia.

Published: 31 May 2018

\section{Introduction}

Bilateral relations between Russia and Ukraine are crucial in the system of the post-Soviet space, so they are the subject of ongoing discussions (Матишов, 2016; Российско-украинское приграничье..., 2011; Суший, 2014). The especially important, pivotal role in the Russian-Ukrainian discourse belongs to its economic component. It contains such aspects as development dynamics and structural proportions of the two countries, the degree, major factors, manifestations and consequences of their economic interdependence, as well as the orientation to other "centers of power", near-border and cross-border cooperation, the contingency of political-ideological and economic interests in shaping bilateral relations, their consonance to European integration, etc. Continuing the discussion of this topic (and taking into account the realities and consequences of the "Ukrainian crisis" as well as the visible growth of the political and economic distance between Ukraine and the Russian Federation), this article is to become an attempt not only to highlight the evolution trend of the economic ties between Russia and Ukraine 
over the past quarter century, but also to show the influence of changing global context, signifying the prospect of a new reconfiguration of geo-economic (and hence geopolitical) landscape of Eurasia.

\section{Post-Soviet evolution dynamics of the economic relations between Russia and Ukraine: geo-economic and geopolitical determinants}

Both Russia (RSFSR) and Ukraine (UkrSSR) were important and deeply inter-integrated frame elements of a single large-scale territorial-economic system in the Soviet Union. The UkrSSR, thus, concentrated a wide range of extractive industries (by the end of 1980 -ies providing $72 \%$ of the USSR's needs in manganese, $48 \%$ - in iron ore, $21 \%$ - in coal (Экономическая и социальная география..., 2004). Also it concentrated the enterprises of the first processing ( $41 \%$ of the country's total production of pig iron, $27 \%$ of steel, $25 \%$ of the rolled metal, etc.), specialized as a supplier of high-tech production (including almost 700 enterprises of the military-industrial complex, which employs more than 1 million highly qualified specialists). The food production specialization provided up to $25 \%$ of total USSR's gross harvest of grain, $22 \%$ of meat in carcass weight, $51 \%$ of the sugar production, $25.9 \%$ of animal and $32.3 \%$ of vegetable oil (СССР и союзные республики..., 1989). The UkrSSR was important (for the Soviet Union) transportation and logistics center (Дергачёв, 1989) and also tourist and recreational area (Мироненко, Твердохлебов, 1981). Ву the end of the 1980s, its contribution in the country's agricultural production has reached to $22.1 \%$, and for the industrial production this figure reached $16.8 \%$, for the national income of the USSR $-17.4 \%$ (which, incidentally, was slightly inferior to the share of the Republic in the population of the Union, which was $18,0 \%$ ). Being densely populated and rich in infrastructure (in comparison with the RSFSR), Ukraine, at the same time, was initially substantially energy-dependent on intra-supply. Its share in 1988 accounted only $4.2 \%$ of the country's total natural gas production and $0.9 \%$ of oil production (CCCP $n$ союзные республики, 1989). And, simultaneously, it was economically non-equal to the RSFSR. With the collapse of the Soviet Union, the economic asymmetry in the system "Ukraine-Russia" has gained even more prominence. While within a single Union space the national income generated by the two republics correlated as 3.75 to 1 (in favor of Russia), in 1991 the ratio of GDP of the two countries was 6.7 to 1, according to World Bank statistics. This fact itself predetermined the inequality of starting opportunities, the subsequent differences in the global positioning of the two countries, as well as the setting of markable periodically increasing center-periphery gradients and the associated interdependencies and contradictions between their economic systems.

Since 1991 continuing economic linkages have becoming unstable, prone to spontaneous erosion, but nevertheless real "braces" in Russian-Ukrainian relations. They, however, gave rise to unstable and, at times, negative foreign policy context (growing, particularly, during the so-called "gas conflicts" in 1993, 2005-2006, 2007-2008, 2008-2009, bilateral restrictions on the supply of goods, etc.). Also they initiated a gradual mental-psychological alienation of the two brotherly, culturally, historically and genetically close peoples, provoking a conflict between their oligarchic groups, political and economic elites.

The inertia of "factor of the Soviet economy" (prolonged in decades collapse of economic and technological interdependencies) at the same time corresponded to the effects of globalization and market transformation. As well it corresponded to the parallelism (but non-identity) in the "embedding" of economic complexes of Russia and Ukraine into the world economic system, their reformatting, "coagulation", gaining peripheral features on the background of the manifested (and increasing) inter-country competition. In the prevailing context of bilateral Russian-Ukrainian relations, the growing influence also gained the geo-economic interests of the major "power centers", transnational companies. The role of geopolitical factors dramatically increased, including a steady (albeit for a short period) unipolarity of the "westernized" world, and simultaneously vividly manifested (including the former Soviet Union) economic, political and mental "eurocentricity" of post-Soviet states, combined with the wavy-consistent expansion of the structures of the "West".

To the beginning of market reforms Russia had lost on the "size" its economy to Germany of more than 4 times, and Ukraine - almost 28 times (GDP at the official exchange rate). Even more substantial were the differences with the group of states that is appropriate to designate as "Old European West"1 (generating in 1991, almost 50\% of the total GDP over the entire Eurasian continent). The lost on the "size" of Russian and Ukraine economy were correspondingly 17 and 115 times. The Western, "European" vector of geo-economic orientation of Russia,

\footnotetext{
1 European States - member of NATO and the EU up to 1991, as well as Austria, Andorra, Cyprus, Malta, Monaco, Liechtenstein, Finland, Switzerland, Sweden.
} 


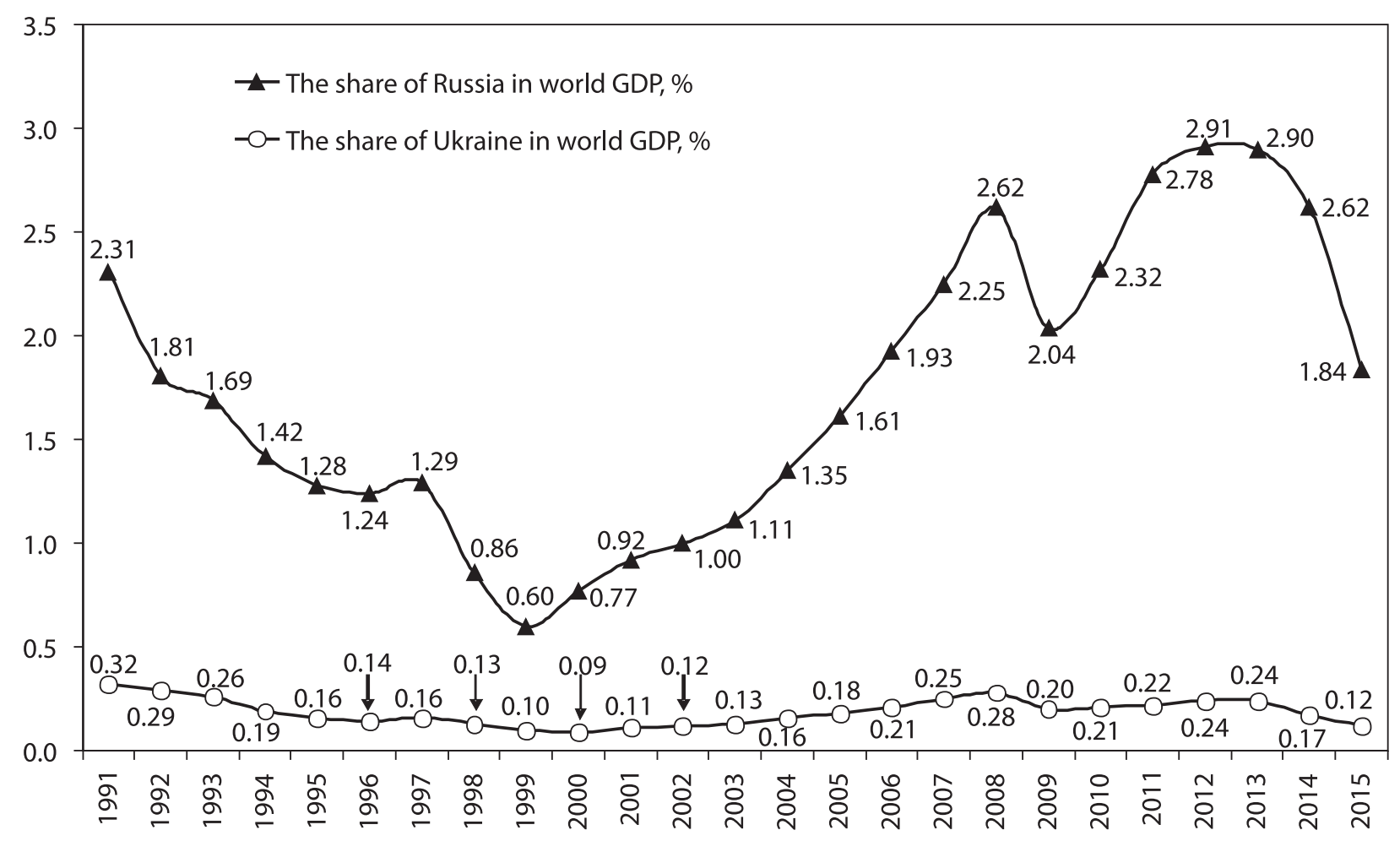

Fig. 1. The share of Russia and Ukraine in world GDP (at the official exchange rate), \%

Source: calculated by the author according to the World Bank data.

Ukraine and other new independent states was almost inevitable in this situation, even without additional account of the economic "weight" and attractiveness of the USA ( $26 \%$ of global GDP) and other non-European closest partners and allies. The subsequent de-industrialization of the both Russian and Ukrainian economies, as well as the their gaining more severe dependent, comprador features only strengthened the process of geo-economic and geopolitical "westernization", producing a destruction of the previously established inter-country economic and technological interactions. Against this background, however, Russian-Ukrainian economic interdependence remained in such spheres as energy, aircraft and aerospace, transportation of hydrocarbons, coal, metals, etc.). Also social and cultural contacts and cross-border relations remained strong prolonged (Российско-украинское приграничье..., 2011). The ethnic-linguistic specificity of Ukraine has played significant role as a component of the Russian ethnic and culture, especially in its South and SouthEastern regions (Мезенцев, Гнатюк, 2014). It has the significant impact on bilateral relations, unstable in its political aspect, accommodating periods of both political trends' divergence of the two countries and their convergence (Ильин, 1998; Политические и экономические..., 2003; Лапкин, 2009). Russian Federation, rapidly losing its former geo-economic (and hence geopolitical) position during all the first
post-Soviet decade (Fig. 1), however, fewer was able to influence the situation in Ukraine. And Ukraine, having acquired the traits of "the two-faced Janus" (Багров, 2002), focused not only on the EU and the US, but also on the East ${ }^{2}$, and in this situation, more and more "drifted" to the West.

The post-crisis recovery economic growth began in Russia since 1999, and a year later in Ukraine. By that time Ukraine has already manifested its "midterm bipolarity" (Дергачёв, 1998), "two-polarity" (Багров, 2002) in full scale. From the turn of 20032004, the most important "driver" for the Russian Federation was the rapid rise of world prices for oil and natural gas (for the period 2001-2007 the price for oil increased 4.8-fold), which had already become the most important item of national exports to that period of time. Opportunistic, illusory role of an "energy superpower state" has strengthened the existing political-economic system, increased the reintegration potential of the Russian Federation in the post-Soviet space, including (partially) its economic attractiveness for Ukraine. In this regard,

2 In 1994 Ukraine and EU signed the "Agreement on Partnership and Cooperation"; also Ukraine signed some agreements with Russia, they are: "Treaty on Friendship, Cooperation and Partnership" (1997); "Agreement on Economic Cooperation for 1998-2007" (1998), "Agreement on Strategic Partnership in Gas Sphere" (2002). 


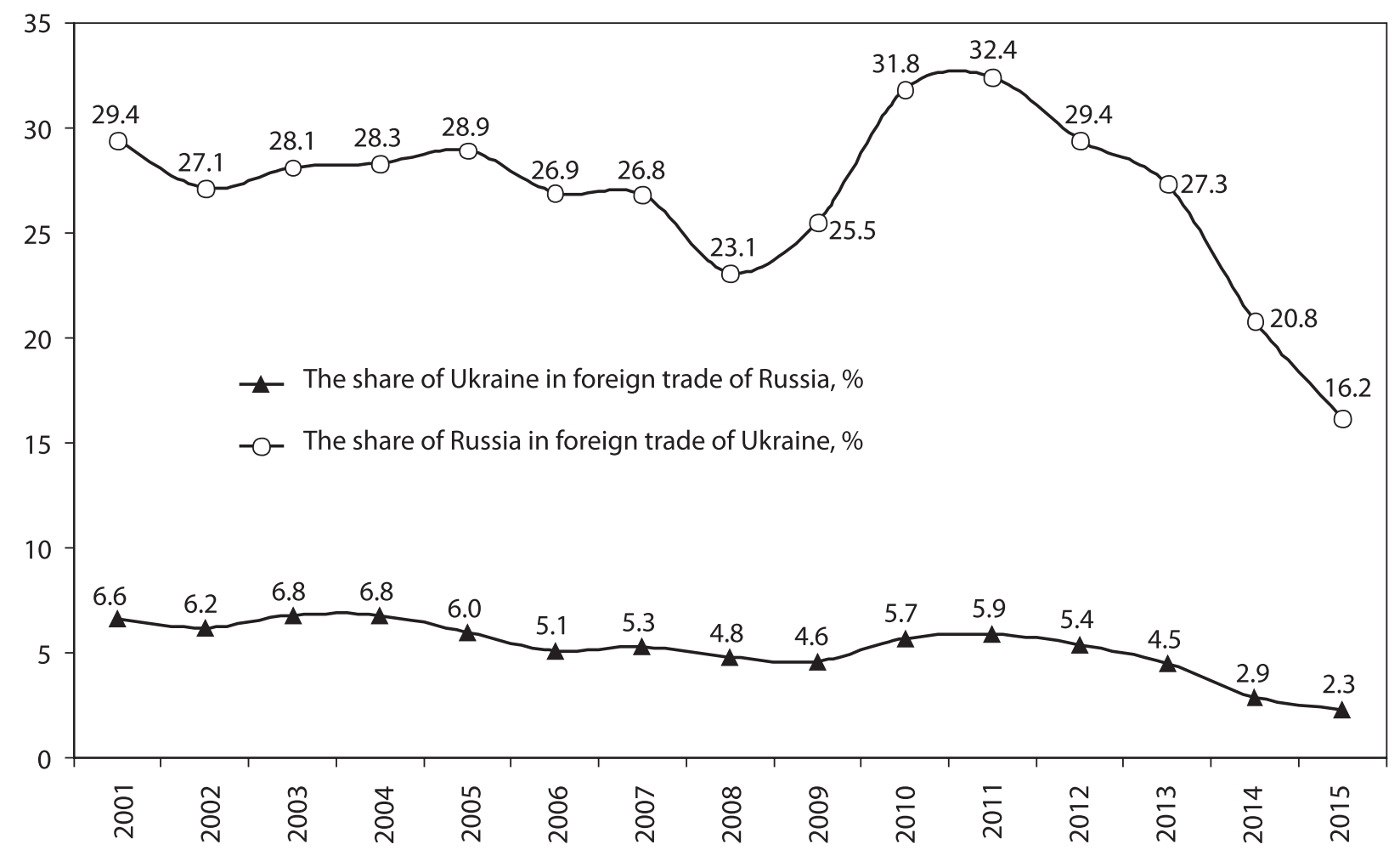

Fig. 2. The share of Ukraine in foreign trade of Russia and vice versa (in progress)

Source: calculated by the author according to the International Trade Centre.

Tab. 1. The share of Russia, Germany and Poland in the export and import of Ukraine (2001-2015, \%)

\begin{tabular}{|c|c|c|c|c|c|c|}
\hline \multirow{2}{*}{ Year } & \multicolumn{2}{|c|}{ The share in the export of Ukraine } & \multicolumn{3}{c|}{ The share in the import of Ukraine } \\
\cline { 2 - 7 } & Russia & Germany & Poland & Russia & Germany & Poland \\
\hline 2001 & 22.4 & 4.2 & 3.1 & 36.6 & 8.5 & 2.8 \\
\hline 2002 & 17.6 & 4.1 & 2.8 & 37.1 & 9.6 & 3.2 \\
\hline 2003 & 18.7 & 6.2 & 3.3 & 37.6 & 9.9 & 3.5 \\
\hline 2004 & 17.8 & 5.7 & 3.0 & 40.2 & 9.4 & 3.4 \\
\hline 2005 & 21.9 & 3.8 & 3.0 & 35.6 & 9.4 & 3.9 \\
\hline 2006 & 22.5 & 3.3 & 3.5 & 30.6 & 9.5 & 4.8 \\
\hline 2007 & 25.7 & 2.7 & 2.7 & 27.8 & 9.6 & 4.8 \\
\hline 2008 & 23.5 & 2.7 & 3.5 & 22.7 & 8.4 & 5.0 \\
\hline 2009 & 21.4 & 3.1 & 3.0 & 29.1 & 8.5 & 4.8 \\
\hline 2010 & 26.1 & 2.9 & 3.5 & 36.5 & 7.6 & 4.6 \\
\hline 2011 & 29.0 & 2.6 & 4.1 & 35.3 & 8.3 & 3.9 \\
\hline 2012 & 25.7 & 2.4 & 3.7 & 32.4 & 8.0 & 4.2 \\
\hline 2013 & 23.8 & 2.5 & 4.0 & 30.2 & 8.8 & 5.3 \\
\hline 2014 & 18.2 & 2.9 & 4.9 & 23.3 & 9.9 & 5.6 \\
\hline 2015 & 12.7 & 3.5 & 5.2 & 20.0 & 10.6 & 6.2 \\
\hline
\end{tabular}

Source: calculated by the author according to the International Trade Centre.

it is markable that the degree of "presence" of Russia in the Ukraine's foreign trade remained stable even during the presidency by V. Yushchenko (Fig. 2), and the significance of the Russian Federation as the most important direction of Ukrainian exports in 2005-2007 even increased slightly (Tab. 1).
According to the State statistics service of Ukraine, during the entire period since 2005 to 2013 the Ukranian exports to the CIS countries has consistently exceeded the same indicator for the European Union. It was distinguished, in this case, by the pronounced "non-primary" character allowing to reproduce the industrial component of the economy 
of Ukraine, partially preserved after the 1990s. In particular, in 2008 the share of engineering products in the total structure of exports to Russia accounted $31.7 \%$; the same figure for metallurgy was $19.6 \%$, and for services - 19.6\% (Российско-украинское приграничье..., 2011). As for the Ukrainian imports, the CIS countries (with an absolute predominance of Russia) took the leading positions in it until 2014 (in comparison with the EU). Corresponding with the strengthening geo-economic positions of Russia (in the 2000s years), the "Eastern vector" in Ukrainian economy continued to dominate on the background of significant (and markable!) geopolitical "progress" in both Ukraine and its neighboring countries of Central and Eastern Europe. In 1999 Hungary, Poland and the Czech Republic were included into NATO; in 2004 the same happen for Bulgaria, Estonia, Latvia, Lithuania, Romania, Slovenia, Slovakia, Estonia; in the same year Hungary, Latvia, Lithuania, Slovakia, Slovenia, Czech Republic, Estonia joined the EU. At the same time the "European neighborhood policy" started. It was addressed also to Ukraine, in which so-called "orange revolution" took place, probably, not by chance "in unison" with the relocation of the Euro-Atlantic borders. In 2007 the EU was enlarged by Bulgaria and Romania. In 2004 the number of countries participating in the EU increased from 15 to 25 , and by 2007 it has increased to 27 . The creation of the single internal market of services has finished. Since 2002 there took place the transition of the economic turnover to Euro currency.

Rapid and large-scale promotion of the West to the East, causing increasingly expressed frustration (and concern) of the Russian Federation, and initiating its growing anti-Western position, objectively turned Ukraine into another significant geopolitical boundary and the areal of confrontation. In this context the position by J. Leveque (Левек, 2016) seems to be right while considering the NATO expansion towards the Russian borders to be the major factor in the formation of Russian policy toward Europe. The attention of the main global and regional actors was focused on the region of confrontation, giving rise for both economic risks and the primacy of geopolitics over economics for Ukraine and Russian Federation.

As V. A. Kolosov noticed in 2011: "Economic factors push Ukraine to the East, while political and ideological factors associated with the tasks of state-building push it to the West" (Российскоукраинское приграничье..., 2011, р. 14). The реriod of "balancing" (between the West and Russia) presidency by V. Yanukovych (2010-2014), indeed, chronologically coincided with the rise in oil prices and, consequently, strengthening the economic position of Russia (whose GDP for 2009-2013 has increased 1.8 times). It was 2011 when both the Russian exports to Ukraine (\$29 billion), and Ukrainian one to Russia (\$19.8 billion) have symptomatically

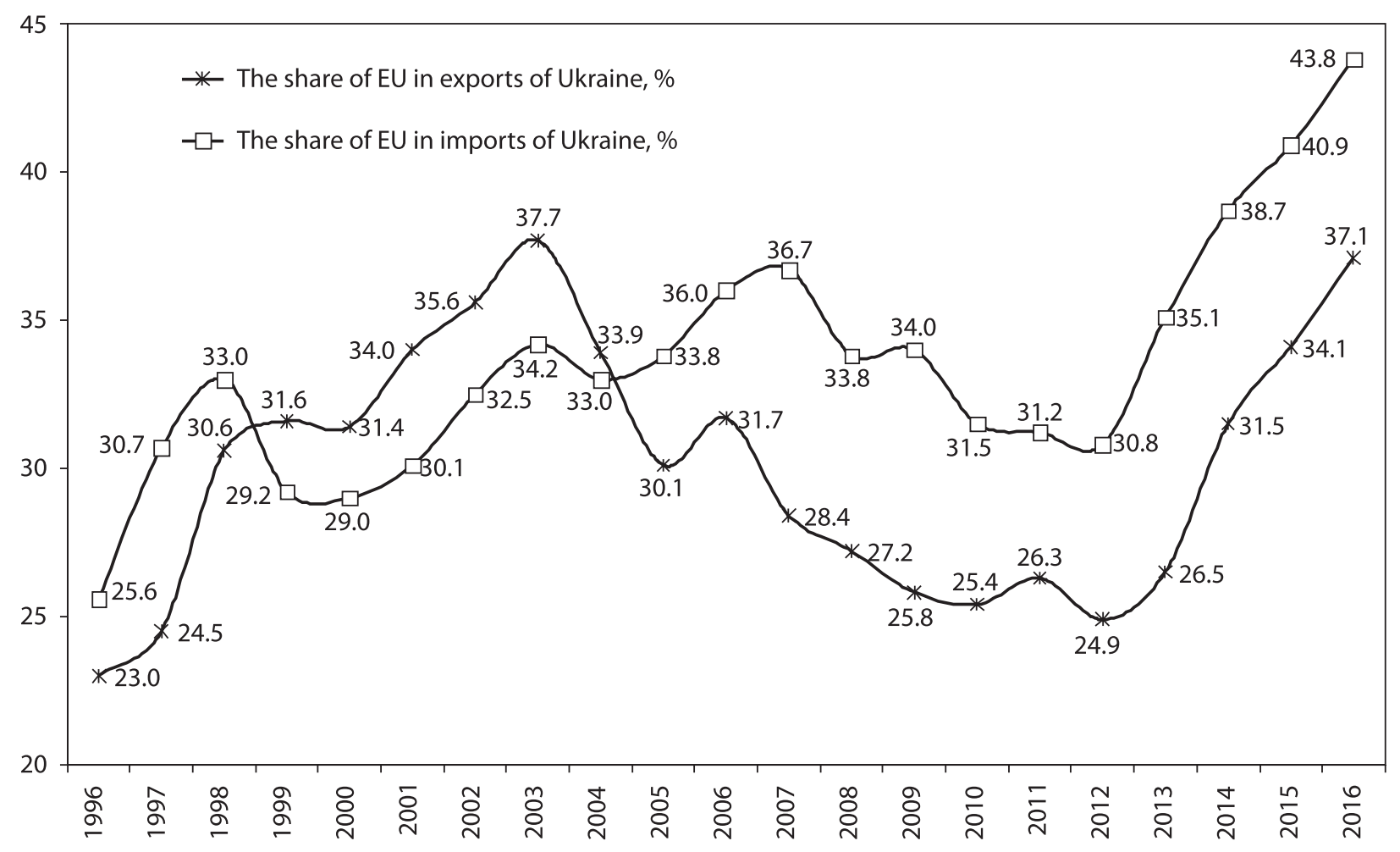

Fig. 3. The share of EU countries in Ukrainian exports (imports) of goods, \%

Source: calculated by the author according to the State statistics service of Ukraine. 
reached the maximum values for the whole postSoviet period. Nevertheless, there were these years, outwardly favorable to bilateral cooperation, when the "peak" in Russian-Ukrainian relations was already passed for many reasons (global, domestic and ones appeared in bilateral relations).

There took place investment interaction: the major assets in Ukraine were bought by TNC "LUKOIL", holding "Group the Alliance", the consortium "Alfa-group", the company "Basic element", AFK "Sistema", "Sberbank", "VTB", etc. It was complied by cooperation in several sectors: automotive, aviation and aerospace, agriculture, energy and nuclear engineering, engine and ship building, nonferrous metallurgy, petrochemical and oil industry (Кузнецов, 2012). Also by 2013 there was achieved the extent of bilateral export-import in the sphere of services for all the post-Soviet history (almost $\$ 6.5$ billion). But against all this background there were growing systemic contradictions between the two countries, and since 2012 their economic interaction was observed to perform sustainable downward trend. First of all there was cooperation in gas sector to be curtailed. This sphere is the most important for the both countries: developing the gas transport infrastructure bypassing Ukraine ("Blue Stream", "Nord Stream", etc.), Russia side by side was steadily losing the Ukrainian market. While in 2006-2008 the volume of natural gas supplied by Russia to Ukraine varied in the range of 55-59 billion cubic meters (in comparison with the post-Soviet maximum at 60.9 billion in 1998). In 2011 (according to "Gazprom") the corresponding figure amounted to 44.8 billion, in 2012 to 32.9 billion, in 2013 to 25.8 billion cubic meters. However, it covered the $85 \%$ of natural gas consumption in Ukraine (Сущенцов, 2015). In this regard, the bilateral trade "saged", while the "European" vector of foreign economic orientation of Ukraine, on the contrary, was steadily increasing (Fig. 3).

However, not only Russian-Ukrainian relations have changed, but also the entire Eurasian ones, as well as the global geo-economic and geopolitical context. New global realities were the fundamental cause of the current economic situation in Russia and Ukraine after the winter-spring 2014. They determined not only quantitative but also qualitative shifts in the interrelations between the two countries (with the major distancing, mistrust and alienation).

\section{The main restructuring trends in the modern economic space of Eurasia and their projection on the Russian-Ukrainian relations}

Having emerged with the collapse of the Soviet Union, the economic dominance of the West (EuroAtlantic geopolitical system) in the Eurasian space proved to be fragile, short-lived, and it was predetermined by a number of significant circumstances.

Primarily, this is due to the strengthening of the economic positions of the Russian Federation in the 2000s. Having significantly increased the extent of the "presence" in the total GRP of the Eurasian continent (3.6-fold) and becoming a significant focus of the generating, accumulation and redistribution of natural resource rents, Russia was able to begin forming its own geo-economic structures (Druzhinin, 2016). Against this background, the Russian economic and cultural presence in some states of Central Asia and Transcaucasia began to grow and partly restored. Since the start of the Customs Union in 2010, the degree of conjugation between the Russian, Kazakh and Belarusian economies became to increase gradually. Integration processes in the economic sphere were reinforced by the "Eurasian Economic Union" (EEU), "started" in 2015. It transformed post-Soviet space not only to the area of acute confrontation between Russia and the West in spring 2014 (Дружинин, 2016), but also to the pole of integration processes, perhaps the most rapidly developing in the modern world according to some expert estimates (Головнин et al., 2016).

However, it was not Russia, India, the Persian Gulf monarchies, Iran, Turkey (all of them simultaneously performed the advanced economic growth), but China to appear the leading driver of radical geoeconomic landscape transformation at the continent. It resulted in the fact that already by 2013 the capacities of the SCO (along with the states tending to this Union) and the aggregate group of countries of the "European West" were almost equal to each other even in such originally "West-centered" indicator as "GDP at the official exchange rate" (Дружинин, 2017) (Tab. 2).

I believe, the desire not only to "traditionally constrain Russia" (Бжезинский, 1998), but also "to deter China" (Брюне, Гишар, 2012), to prevent unwanted changes in the global balance of power - is one of the fundamental reasons for the expansion of the

\footnotetext{
3 In the calculation of GDP at purchasing power parity (PPP) the share of "European West" in 2015 is not exceeded $26.8 \%$, while the SCO with the states-partners reached the figure $48.8 \%$.
} 
Tab. 2. Relative weight of individual metaregions, integration associations and states in the total GDP on the Eurasian continent (at the official exchange rate), \%

\begin{tabular}{|l|r|r|r|r|}
\hline & 1992 & 2000 & 2013 & 2015 \\
\hline States of the Eurasian Economic Union & 2.82 & 1.41 & 5.18 & 3.37 \\
\hline inter alia Russia & 2.57 & 1.25 & 4.52 & 2.83 \\
\hline «Old European West» & 49.61 & 44.39 & 38.33 & 36.36 \\
\hline «New European West»*${ }^{*}$ & 1.66 & 2.06 & 2.89 & 2.74 \\
\hline States-members of the SCO & 7.30 & 9.91 & 28.83 & 31.84 \\
\hline China & 2.58 & 5.84 & 19.45 & 23.41 \\
\hline Japan & 21.54 & 22.83 & 9.94 & 8.77 \\
\hline India & 1.64 & 2.30 & 3.77 & 4.46 \\
\hline Turkey & 0.88 & 1.28 & 1.67 & 1.52 \\
\hline Saudi Arabia & 0.76 & 0.91 & 1.51 & 1.37 \\
\hline Iran & 0.48 & 0.53 & 1.03 & 0.93 \\
\hline Ukraine & 0.40 & 0.15 & 0.37 & 0.19 \\
\hline
\end{tabular}

* - Albania, Bulgaria, Hungary, Latvia, Lithuania, Poland, Romania, Slovakia, Slovenia, Czech Republic, Croatia, Estonia.

Source: Compiled by the author according to the World Bank.

Euro-Atlantic structures into the East and South-East direction during all the last years. In recent years, the West rapidly "stake out territories", reformatting and readjusting the country's economies. It aims to transform local identity, but the real geo-economic effect from the post-Soviet expansion is small. Its new peripheral gains only partially offset the "trend flow" of economic and demographic potential to the East, South and South-East of Eurasia, that has been for almost a decade (Хесин, 2010). There is also no fullextent solution to internal tasks, such as: to pause stagnation and disintegration processes within the EU, to prove the feasibility of the NATO's presence and to increase its effectiveness, because its expansion is also at an impasse, as analysts acknowledge (Левек, 2016).

The "revolution of dignity" (aka - "the state coup"), having accomplished in winter 2014 with all the variety and substantialness of internal Ukrainian motives, seems to be only a fragment, one of the "whipping grounds" for the global geopolitical interests, triggered by the major economic and demographic changes (the "tectonic shifts" in the terms by V.A. Shuper (Шупер, 2016)). They are multifaceted, unpredictable in consequences; their symptoms are significantly corrected by global and country economic rhythm and conjuncture.

Being only partly associated with the "Ukrainian crisis", the major shifts in global energy markets have made a blow not only to the economy of Russia, but also to the economies of many neighboring Eurasian states. So, since August to December 2014 the world price of oil have felt almost 2.5 times and further stabilized by about $40-45 \%$ from the previous level. For 2013-2015, the total GDP of the twelve countries
- leading suppliers of oil and natural gas localized in Eurasia decreased from $\$ 4.9$ to $\$ 3.6$ trillion, i.e. by a third. In this regard, even against a planned British exit from the EU, there seem to retain reasonable the assumptions that "the process of European integration is far from being complete" (Шейнис, 2017), and the European Union continues to be perceived (and probably actually stay) as "the most developed and successful integration Union" (Головнин et al., 2016).

Time, however, does work neither on United Europe, nor on the USA. It is more and more difficult for them to control Eurasian mainland, acquiring multipolarity and having actually prevailing on a global scale not only demographically, but also economically (in 2015, the total PPP GDP of the Eurasian countries amounted to $\$ 82.4 \mathrm{bln}$., equivalent to $69 \%$ of the world total, and is just over 47 billion, or $63.4 \%$ at the official exchange rate). And the leading actor (the initiator and sponsor) of modern transnational-Eurasian integration processes is China with its "creative expansion" (Федоровский, 2016), which has been manifesting since 2013-2014, and virtually uncontested "continentalization" of its sphere of influence.

While realizing its factually global geo-economic project, the "Middle Kingdom" (Zhongguo - 中 国) already dominates at the markets of Pakistan, Tajikistan, Kyrgyzstan, Iran, Mongolia and has substantial interests in India and the states of Persian Gulf. The transcontinental transit is increasing, being supported by the economic growth in China; also there take place major infrastructure projects (Дружинин, 2017). Russia also gradually reconfigures its economy to the PRC (while in the first quarter of 2008 China's share in foreign trade turnover of the Russian Federation was 7.8\%, in 2014 it was 
$11.1 \%$, and in $2017-14,3 \%$ ). The same changes occur, for example, in Turkey; they are typical as well for Ukraine. In this regard the concept of "One belt and one road", formulated by Chinese President XI Jinping in the autumn 2013, appears to be markable and, in fact, the common for all the Eurasian space (Китайский глобальный проект..., 2016). It signifies the prospect of a new reconfiguration of geo-economic (and hence geopolitical) landscape of Eurasia. Having found the geo-economic vector primarily focused on the West over the past quarter century, both Ukraine and Russia (as well as a number of adjacent states) appear to be in the area of geo-strategic uncertainty, disengagement, conflicts of interests by obvious and latent "power centers" with the inevitable confrontation and the concomitant crisis processes in the economic sphere.

\section{The crisis in Russian-Ukrainian relations in 2014-20....: some geo-economic results}

Visible, multi-faceted crisis in Russian-Ukrainian relations has affected the economic sphere in a full-scale. Its negativity was multiplied by a conjuncture in the energy markets. The most noticeably and painfully the crisis manifested in Ukraine.

Probably Ukrainian society partly "returned to the European vector" (Руденко et. al., 2016); however, the actual price for the division of the country, as well as the intensification of geopolitical and geoeconomic "divorce" with Russia appeared to be extremely high. Outside of Ukrainian jurisdiction there remains about $12 \%$ (in comparison with the state in 2013) of the population and productive assets, providing up to $11 \%$ of the total volume of the gross regional product. For the period of 2014-2015 the GDP of Ukraine has dropped twice (from $\$ 183$ billion in 2013 to $\$ 91$ billion in 2015), and only in 2016 (according to the Ukrainian statistics) the economy has shown some growth $(2.3 \%)$, while the foreign trade turnover thus fell 1.86 times (and the $40 \%$ of this fall is due to the "collapse" of relations with Russia). Having gained the status of the "state with market economy" (only in 2006) and failed the attempts to restore the GDP level of 1990 during all the post-Soviet period (Геєць, 2016), Ukraine have plunged into new investment "hole", as it note Ukrainian economists (Крючкова, 2016). Instead of investment progress which is necessary for the implementation of neo-industrialization, the regression prevails in the country. In both 2016 and early 2017 the state statistics record a decline in the industrial sector of Ukraine. The precarious financial state of industrial enterprises causes the shortage of own funds and debt bondage, not allowing to maintain the necessary level of gross savings and therefore, gross fixed capital formation. Permanent decline in net profits leads to attenuation of investment activity in the industry (Шовкун, 2016).

Both the crisis in bilateral relations and the extension of de-industrialization have contributed to the accelerated fall in the purchases of Russian natural gas by Ukraine (7.8 billion cubic meters in 2015), which de facto turned the country into the secondary market for "Gazprom" and its subsidiaries. In turn, Ukraine has lost the Russian food market which was traditionally significant for a number of its regions, especially in the South (Shelest, 2015). Being triggered by sanctions, the policy of import substitution in Russia perform the effectiveness in key positions. Even in the face of economic crisis of 2013-2016 the meat production of cattle in the Russian Federation grew by $9 \%$, pork - by $53 \%$, poultry - by $24 \%$, butter - by $10 \%$, cheese - by $38 \%$ (Росстат, 2017). In comparison the Ukraine's share in the food goods imported by Russia account only $0.5 \%$ in the 1 st quarter 2017 (that is equivalent to $\$ 33.9$ million). In general, Russia's share in Ukrainian exports accounts only $9 \%$, and imports $13.4 \%$ to the 1 st quarter of 2017 . The share of Ukraine in foreign trade of the Russian Federation in the same period reached $2 \%$, that is also the lowest rate over the entire post-Soviet history (Федеральная таможенная служба, 2017). It is markable that for both exports and imports the Russian Federation continued to be a prior (leading other countries) foreign trade partner of Ukraine.

Not only the Ukrainian economy but also the Russian one has substantially suffered over the past three years. The volume of foreign trade of the Russian Federation "cringed" 1.6 times, and GDP - 1.63 times. A substantial decrease took place in the investment activity (its volume in 2016 amounted to only $88 \%$ of the level in 2013). According to the value of GDP generated by economy (official exchange rate), Russia was thrown back to 2007, and Ukraine - to 2005 (The World Bank, 2017). As a result, both countries performed a very high degree of dependence on global economic rhythm, as well as on the earlier economic partnerships.

It is markable that until 2014, Russia not only performed the dense geo-economic "bundle" with Ukraine, but in 2000-2008 and 2010-2013 was largely a kind of "locomotive" for it. There were these time periods of global economic situation being favorable for Russia, when Ukraine has increased its share of global GDP. However, during all the postSoviet period Ukraine has never broke the starting bar of 1991 (and Russia, I should notice, has done it in 2008, as well as during 2010-2014). In 1999 
the ratio of the "mass" of the Russian and Ukrainian economies was 6 to 1, and in 2013 it became 12.2 to 1 . The degree of economic influence of Russia to Ukraine in this situation has objectively significantly increased. In 2015 the Russian and Ukrainian economies correlated already at 15 to 1 (by GDP), and the deepening asymmetry projected on the income of the population, its consumption potential and the cost of labor. For the situation in the middle 2017 the average salary in Russia was equivalent to $\$ 610$, and in Ukraine it accounted $\$ 290$. Of course, in this context the Russian vector of "socio-economic gravity" is essential for Ukraine both now and in the future (in the coming "post-crisis" period).

But since 2008 the Russian economy is, in fact, "marking time". The restoration of the geo-economic positions of the country to the level of 2008 will require at least 5-7 years even with a favorable scenario. At the same time the post-Soviet generations have entered the economic and political life in Ukraine. And in this context, it should be noticed the sharp decline in the attractiveness of Russia for Ukrainian households, which are foreign-oriented for working activity. Such trend is typical for the last years, and every fifth family in Ukraine has its member temporarily working in another country (Прибыткова, 2003). Ukrainian society is visibly reorienting to the labour markets of Western and Central European countries. It is symptomatic that the amount of remittances of physical persons from Russia to Ukraine amounted only $\$ 1.25$ billion in 2015, while in 2013 it was $\$ 3.42$ billion (according to the CB RF). And this is just one of the faces of the structural reformatting of the Ukrainian economy, rapidly implemented nowadays with the use of mostly geopolitical (and geo-ideological) methods. This process results for Ukraine in the deepening, prevalent orientation to the West and taking the role of a sales market, the "reservoir" of labour, as well as the supplier of agricultural products. The task to destruct the "Ukrainian component" in the Russian economy is to be solved simultaneously. As V.V. Pantin and B.I. Lapkin suggest (Пантин, Лапкин, 2012), the loss of the Ukrainian market will limit the possibilities of economic development of Russia. All these is to be made in the interests of Western corporations (and their Russian branches), and is aimed to provide the geo-economic "containment" of the Russian Federation, as well as "cleansing" some segments of the Russian market from Ukrainian producers which, by the way, are keeping interest in the Russian market (Shelest, 2015). Of course, the geo-economic and geopolitical struggle takes place not so much "for Ukraine", but "for Russia" as the main hub fragment of the Eurasian space.

\section{Conclusion}

Being the trend of all the post-Soviet period (and only accentuated by the geopolitical events of the last three years), the degradation and disaggregation of Russian-Ukrainian relations marks the actual exhaustion of the "Soviet Union inertia". Also it marks the new Eurasian reality, in which neither Russia (despite the vastness of its territory and the continuing military-strategic potential), nor, especially, Ukraine can longer be able to claim any leadership position in acquiring multi-polar planetary economic center-periphery system. Ukraine was caught in the geopolitical millstone between Russia and the West (Лапкин, Пантин, 2014) and appeared to be in the area of depopulation, aside from the dominant transportation and logistics braces and geo-economic axes of interaction. However, the emphasis on internal issues of government construction and national interests, as well as the geopolitical disengagement initiated by global processes - abolish neither significance of the geo-economic neighbourhood for both Russia and Ukraine, nor the affinity of cultural and behavioral codes, having formatted during the centuries of mutual geohistory. Also it does not abolish the ethno-cultural, socio-demographic, environmental, economic and geopolitical challenges which are common to both countries. At the present time the Russian-Ukrainian economic interdependence is disappearing in many aspects, being "substituted" by the relations with the EU (and already in the medium term the same role can play the relations with China). But in the mentioned context of geohistorical and cultural commonality doubled by the common challenges of nowadays, this interdependence retains its foundations, reasons, and, I hope, positive prospects.

\section{Acknowledgements}

The research was carried out at the expense of a grant from the Russian Science Foundation (project № 18-17-00112 «Ensuring economic security of Russia's western border regions in the conditions of geopolitical turbulence»)

\section{References}

Database of International trade center, http://www.intracen.org/itc/market-info-tools/statistics-import-countryproduct/ [14.06.2017].

Database of the State statistics service of Ukraine, http:// www.ukrstat.gov.ua/ [12.06.2017]. 
Druzhinin A., 2016, Russia in modern Eurasia: The Vision of a Russian Geographer, Quaestiones Geographicae, 35(3), 31-39.

Shelest H., 2015, After the Ukrainian crisis: Is there a place for Russia? Southeast European and Black Sea Studies, 15(2), 191-201.

The World Bank. World development indicators, http://databank.worldbank.org/data/reports.aspx?Code=NY.GDP. MKTP.CD\&id=1ff4a498\&report_name=Popular-Indicator s\&populartype=series\&ispopular=y [10.06.2017].

Багров Н.В., 2002, Региональная геополитика устойчивого развития, Лыбидь, Киев.

Бжезинский 3., 1998, Великая шахматная доска. (Господство Америки и его геостратегические императивы), Международные отношения, Москва.

Брюне А., Гишар Ж.-П., 2012, Геополитика меркантилизма: новый взгляд на мировую экономику и международные отношения, Новый хронограф, Москва.

Геєць В.М., 2016, 25 Років трансформаційних змін. Що далі? Економіка і прогнозування, 2, 7-8.

Головнин М., Захаров А., Ушкалова Д., 2016, Экономическая интеграция: уроки для постсоветского пространства, Мировая экономика и международные отношения, 60 (4), 61-69.

Дергачёв В.А., 1989, Морехозяйственный комплекс Азово-Черноморского региона СССР: экономико-географические аспекты, [in:] Южные моря СССР: географиче ские проблемы исследования и освоения, Геогр. об-во СССР, Ленинград, 39-50.

Дергачёв В.А., 1998, Раскалённые рубежи. «Астропринт», Одесса.

Дружинин А.Г., 2016, Россия в многополюсной Евразии: взгляд географа-обществоведа, Издательство Южного федерального университета, Ростов-на-Дону.

Дружинин А.Г., 2017, Геоэкономические взаимозависимости и геополитические альянсы в современном евразийском пространстве, Сочиально-экономическая география. Вестник АРГО, 6, 24-38.

Ильин М.В., 1998, Этапы становления внутренней геополитики России и Украины, Полис, 3, 86-90.

Китайский глобальный проект для Евразии: постановка задачи (аналитический доклад), 2016, Научный эксперт, Москва.

Крючкова І.В., 2016, Макроструктурный дизайн економік українита країн ОЕСР, Економіка і прогнозування, 3, 7-28.

Кузнецов А., 2012, Российские прямые инвестиции в странах СНГ, Международные прочессы, 2, 18-28.

Лапкин В.В., 2009, Украина и Россия. Альтернативы политического развития, Мировая экономика и международные отношения, 12, 78-89.

Лапкин В.В., Пантин В.И., 2014, Кризис украинской государственности: политико-правовой, ценностный и геоэкономический аспекты, Polis. Political Studies, 5, 68-89.

Левек Ж., 2016, Российская стратегия в контексте украинского кризиса: следует ли ожидать пересмотра Рах Americana в Европе?, [in:] Россия - 2016. Ежегодный доклад. Франко-российский аналитический центр «Обсерво», Париж, 186-195.
Матишов Г.Г., 2016, Опасные тенденции и риски на южном фланге России, Южный научный центр РАН, Ростов-наДону.

Мезенцев К.В., Гнатюк А.М., 2014, Русская культура в Украине: региональные тренды и идентичность, [in:] А.Г. Дружинин, В.Н. Стрелецкий (eds.), Феномен культуры в российской общественной географии: экспертные мнения, аналитика, концепты, Изд-во ЮФУ, Ростовна-Дону, 378-397.

Мироненко Н.С., Твердохлебов И.Т., 1981, Рекреационная география, Изд-во Московского ун-та, Москва.

Пантин В., Лапкин В., 2012, Внутри- и внешнеполитические факторы интеграции Украины с Россией и ЕС, Мировая экономика и международные отношения, 11, 50-56.

Политические и экономические преобразования в России и Украине, 2003, „Три квадрата», Москва.

Прибыткова И.М, 2003, Трудовая миграция населения Украины в условиях трансформации, [in:] Трудовая миграчия в СНГ: сочиальные и экономические эффректы, Институт народнохозяйственного прогнозирования РАН, Москва, 17-31.

Российско-украинское приграничье: двадиать лет разделённого единства, 2011, Новый хронограф, Москва.

Росстат. База данных, http://www.gks.ru/ [14.06.2017].

Руденко Л.Г., Лісовський С.А., Маруняк Є.О., 2016, Выклики і загрози просторового развиитку України на шляху до євроінтеграції, Український географічний журнал, 1, 41-46.

СССР и союзные республики в 1988 году, 1989, Финансы и статистика, Москва.

Сущенцов А., 2015, Аналитический доклад: новая украинская политика России, http://www.foreignpolicy.ru/ analyses/novaya-ukrainskaya-politika-rossii [17.06.2017].

Сущий С.Я., 2015, Украина - Россия - Мир: до и после 2014 года (некоторые аспекты взаимодействия), Ленанд, Москва.

Федеральная таможенная служба. База данных, http:// www.customs.ru/ [15.06.2017].

Федоровский А., 2016, Россия и вызовы Восточной Азии, Мировая экономика и международные отношения, 60(3), 58-71.

Хесин Е.С., 2010, Меняющийся глобальный экономический ландшафт, [in:] Л.М. Синцеров (ed.), География мирового развития, Товарищество научных изданий КМК, Москва, 22-42.

Шейнис В., 2017, Европейская интеграция вчера и сегодня, Мировая экономика и международные отношения, 61(1), 53-66.

Шовкун І.А., 2016, Неоіндустріалізація в Україні: чи $\epsilon$ макроекономічні передумови та інвестиційний потенціал?, Економіка і прогнозування, 4, 48-69.

Шупер В.А., 2016, Территориальная организация населения и хозяйства России накануне тектонических сдвигов, [in:] В.М. Котляков, В.Н. Стрелецкий, О.Б. Глезер, С.Г. Сафронов (eds.), Проблемы регионального развития России, series: Вопросы географии. Сб. 141, Издательский дом «Кодекс», Москва, 529-539.

Экономическая и социальная география стран ближнего зарубежья, 2004, Дрофа, Москва. 